\title{
Małgorzata Bańkowska
}

Państwowa Wyższa Szkoła Zawodowa

im. Prezydenta Stanisława Wojciechowskiego

e-mail:m.bankowska@bu.pwsz.kalisz.pl

\section{Marek Hetmański, Świat informacji Warszawa: Difin, 2015. 233 ss.}

\section{DOI: http://dx.doi.org/10.18778/0860-7435.27.06}

Pozornie wydawać by się mogło, że na temat informacji, rozumianej jako zasób i budulec wiedzy, ale też wysokodochodowy towar rynku biznesowego i nie tylko, wiemy już niemal wszystko. Istniejąca bogata literatura przedmiotu zdaje się wyczerpywać problematykę tego złożonego i interdyscyplinarnego zjawiska. Tym samym kolejne próby opracowania tematu rodzą zagrożenie oczywistych powtórzeń i nieodkrywczych analiz. W tej perspektywie jako nowatorskie jawią się jedynie te próby badawcze, które sytuują informacje jako zjawisko społeczne w nowym kontekście dziedzinowym i metodologicznym oraz maja charakter ponadczasowych analiz. Do takich opracowań zaliczyć można wnikliwe studium informacji autorstwa profesora Uniwersytetu Marii Curie-Skłodowskiej Marka Hetmańskiego o znamiennym tytule Świat informacji. Monografia, inspiracją dla powstania której stały się wykłady prowadzone przez autora dla studentów filozofii, kogniwistyki oraz bibliotekoznawstwa $\dot{i}$ informacji naukowej udowadnia, że o procesach informacyjnych wciąz można mówić nowym językiem, w świeżej epistemologicznej perspektywie badawczej. Książka stanowi wyzwanie do poznawczego i myślowego wysiłku zgłębienia „rzeczywistej roli informacji we współczesnym świecie” (s. 9). Autor szanuje czytelnika konstruując teorie oparte na poglądach największych światowych filozofów, logików, językoznawców oraz teoretyków literatury 
i komunikacji społecznej. W opracowaniu znajdujemy m.in. odwołania do myśli Romana Jakobsona, Umberto Eco, Kazimierza Ajdukiewicza i wielu innych.

Praca podzielona została zgodnie $\mathrm{z}$ najlepszymi praktykami w zakresie publikacji naukowych na cztery zasadnicze rozdziały poprzedzone Przedmowa (s. 7-12), zwieńczone zaś zakończeniem z intrygującym podtytułem: Jak radzić sobie z informacja (s. 203-224). Wartość opracowania podnosi umieszczenie $\mathrm{w}$ aparacie pomocniczym obok literatury przedmiotu także indeksu terminów i nazwisk.

Rozdział pierwszy - Co oznacza i co znaczy ,informacja” (s. 13-40) poświęcony został słownikowym i encyklopedycznym definicjom pojęcia oraz autorskim propozycjom terminologicznym, ze wskazaniem na etymologię nazwy oraz na konstytutywne i konsekutywne cechy informacji. Dokonując analiz terminologiczno-kategorialnych autor $z$ naciskiem konstatuje, że „nazwa «informacja» jest nazwą nieostrą, gdyż zarówno w praktykach lingwistycznych języka potocznego [...], jak i w regułach semantycznych języków specjalistycznych [...] nie ma jednakowo prostych zasad wyznaczania jej zakresu" (s. 27).

Do najbardziej oryginalnych i interesujących z perspektywy badań interdyscyplinarnych należy rozdział drugi - Metafory informacyjne (s. 41-80) poświęcony ,językowym środkom stylistycznym” (s. 41) komunikatów społecznych. Ich cechą charakterystyczną jest to, że „mówią coś nowego i oryginalnego zawsze w ramach wiedzy już posiadanej" (s.78). Badacz zwraca uwagę na umiejscowienie metafor w porządku lingwistycznym i kulturowym oraz podkreśla znaczenie figur językowych w procesach komunikacji społecznej (wpływ na „strukturę pojęciową" - myślenia i języka oraz na „praktyczną postawę człowieka”, s. 47). Analizie poddana została wartość informacyjna wybranych metafor oraz ich szczegółowe funkcje, do których prof. Hetmański zalicza: 1) opis złożonych zjawisk informacyjnych, 2) twórcze ujęcie rzeczywistości, 3) przywoływanie, przechowywanie, zapamiętywanie (magazynowanie) wiedzy, 4) ocenianie procesów informacyjnych, 5) wywoływanie emocjonalnego nastawienia, 6) komunikowanie treści, 7) pobudzanie do działania, 8) przekonywanie do zalet i korzyści. Wśród figur „lingwistyczno-komunikacyjnych" (s. 57) o istotnym potencjale semantycznym i poznawczym szczególowej analizie poddane zostały m.in. zwroty typu: Media to przedlużenie żmystów (za: M. McLuhan, s. 56), Informacja jest drugim potopem (za: P. Lévy, s. 70), Informacja to krwiobieg $i$ spalanie w maszynie (za: J. Gleick, s. 72), Informacja kodowana jako kawa instant (za: P. Levinson, s. 58), Informacja to pożeranie (za: J. Baudrillard, s. 61), Informacja jako odpadki (za: S. Lem, s. 67).

Rozdział trzeci - Informacja i komunikacja (s. 81-152) poświęcony został systemom komunikowania. Autor wychodząc od omówienia zależności onto- 
logicznych między informacją (wiedza) a komunikacja (uznaje, że ta ostatnia jest „formą dla treści” (informacji)) dokonuje przeglądu najważniejszych koncepcji i teorii wypracowanych w obszarze różnych dziedzin naukowych a odnoszących się do procesów społecznego komunikowania. Część ta stanowi analityczny wykład poglądów: Claude’a Shannnona, Warrena Weavera, Norberta Wienera, Gregory'ego Batesona, Dana Sperbera, Deirdre'a Wilsona, Waltera Onga, Umberto Eco i Romana Jakobsona. Prezentacja modeli i mechanizmów komunikacji międzyludzkiej stanowi punkt wyjścia do rozważań oscylujących wokół filozofii informacji oraz czynników kreujących cywilizację informacji.

Rozdział czwarty - Cywilizacja informacji (s. 153-201) jest zwieńczeniem prowadzonego z pełną konsekwencją badawczą dyskursu i zawiera przegląd najważniejszych zjawisk informacyjnych współczesnego świata oraz dyscyplin naukowych zajmujących się ich analiza. W obszarze badawczego zainteresowania znalazły się te czynniki, „które przyczyniły się do powstania w drugiej połowie minionego stulecia specyficznego zwrotu informacyjnego" (s. 10), a do których zalicza się rewolucje przemysłowe i wykreowane przez nie sposoby myślenia. Cechą zasadniczą zwrotu, którego skutkiem są zmiany cywilizacyjno-kulturowe (s.155) jest, zdaniem autora, zastosowanie i umocnienie „kategorii informacji w nauce (od fizyki i informatyki przez biologię czy psychologię po nauki społeczne) oraz w potocznym doświadczaniu świata" (s. 154). Odwołując się do teorii Keitha Devlina prof. Hetmański podkreśla znaczenie postawy informacyjnej jako programu badawczego wynikającego z „tendencji do określonego myślenia i działania wobec zjawisk informacyjno-komunikacyjnych" (s. 159). Ciekawą dyrektywą metodologiczna jest tu wskazanie na naukę o informacji, informatologię oraz bibliotekoznawstwo jako dyscypliny, które wraz z informatyką biorą udział w informacyjnej rewolucji (s. 174-181). Ich znaczenie osadza się na gromadzeniu, przetwarzaniu i udostępnianiu nośników informacji oraz tworzeniu zasobów informacyjnych.

Pewien niedosyt poznawczy rodzi podrozdział zatytułowany Gdzie $i$ od kiedy squkać informacji (s. 163-165). Zorientowany w problematyce informacji (teorii informacji) czytelnik oczekuje tu raczej wyszczególnienia konkretnych źródeł informacji (w określonym porządku klasyfikacyjnym) i określenia ich wartości poznawczej. Autor natomiast konstruuje oczywista myśl, że informacja jako podstawowy wyznacznik komunikacji, towarzyszyła człowiekowi „zawsze i była wszędzie” i wskazuje na podstawowe elementy procesu komunikowania (materialne nośniki, narzędzia i środki utrwalania, systemy magazynowania i komunikowania) oraz sposoby przekazu informacji (mowa, teksty, obrazy, muzyka, multimedia). 
W Zakończeniu (s. 203-224) autor wyjaśnia użyte w tytule pracy pojęcie „świata informacji” (,świat codziennych zachowań poznawczych i praktycznych człowieka"(s. 204)) i w tym kontekście stawia pytanie o metodologiczna wartość kategorii informacji oraz zasady jej funkcjonowania w nauce (s. 165). Podjęta analiza pokazuje, że pojęcie informacji mieści w sobie nie tylko odniesienia do jej cech własnych, ale także uwzględnia sposoby „prezentacji oraz interpretacji zjawisk informacyjnych" (s. 204). Toteż zdaniem badacza przy konstruowaniu modeli informacji wymagane jest uwzględnienie podmiotu (,wyposażonego w akty poznawcze” (s. 211)) oraz narzędzi przetwarzających informację (domena informatyki) i środków komunikowania informacji. We wskazaniach tych trudno dopatrzeć się odkrywczych tez. Oryginalne jest natomiast filozoficzne ujęcie problemu.

Rozważania końcowe zamyka próba określenia zagrożeń związanych z nadmiarem oraz niedoborem informacji. Próba w rzeczy samej karkołomna. Autor obnaża funkcjonującą w świecie mediów niepisaną zasadę nacisku informacyjnego („informatyczny imperatyw kategoryczny”), którą formułuje następująco: „Należy postępować (czytaj: obsługiwać komputery i użytkować programy) zawsze wedle takich regul (algorytmów i praw rynku), co do których chcielibyśmy (my informatycy, menedżerowie komputerowych firm, monopoliści), aby były one stosowane przez każdego (użytkownika, kupującego, klienta serwisów) i zawsze (najlepiej w czasie obowiązywania kolejnych up-date'owych wersji) ku powszechnej korzyści wszystkich ludzi” (s. 223). Jako formę przeciwdziałania destrukcyjnym skutkom ekspansywnych procesów informacyjnych filozof proponuje respektowanie reguł tworzonych przez użytkowników informacji oraz stworzenie „możliwości dokonywania wyborów i podejmowania decyzji na podstawie adekwatnego rozpoznania sytuacji informacyjnych" (s. 224).

Całość opracowania tchnie oryginalnością naznaczoną wysokiej próby metoda badawczą oraz umiejętnością konstruowania spójnego, choć skomplikowanego wywodu naukowego osadzonego w kontekście semantyczno-lingwistycznym. Prof. Hetmański nie stroni od odwołań do odważnych tez, m.in. Erika Davisa, odsłaniających cywilizacyjne, psychiczne i duchowe zagrożenia technokulturą i z determinacją wskazuje na wpływ technik informacyjnych na działania i moralność człowieka. Ten ze wszech miar interesujący dyskurs ma jednak charakter hermetyczny ze względu na terminologię i konstruowanie typowych dla nauk filozoficznych struktur myślowych. Lekturę niewatpliwie ułatwia dysponowanie wiedzą z zakresu filozofii, w tym zwłaszcza teorii poznania.

Mimo niezwykłej rzetelności badawczej oraz widocznej dbałości o uporządkowanie terminologiczne pojęć związanych z informacją autor nie unik- 
nął błędów. W dywagacjach na temat pojęć: „informacja naukowa”, „bibliologia”, „bibliotekoznawstwo” (s. 174, przypis 35) pojawiły się dwa błędne stwierdzenia. Pierwsze dotyczy uznania terminów „nauka o informacji”, „,bibliotekoznawstwo”, „,informatologia” i „bibliologia” za równorzędne znaczeniowo, a zatem synonimy. Drugie, podobne pierwszemu, zawiera mylne wyjaśnienie, że termin ,informacja naukowa” był dawniej (to znaczy kiedy?) synonimem „bibliotekoznawstwa. Są to istotne nieścisłości terminologiczne i szkoda, że pojawily się w tak poważnej pracy ${ }^{1}$.

Monografia prof. Marka Hetmańskiego pokazuje, że problematyka złożonych procesów informacyjnych współczesnego świata stała się przedmiotem zainteresowania niemal wszystkich dziedzin naukowych, nie wyłączając nauk humanistycznych. Autor udowadnia, że o informacji można mówić na różne sposoby i wielu kontekstach metodologicznych oraz przy zastosowaniu różnych systemów pojęciowych. Mimo jednak licznych wysiłków reprezentantów szeregu dyscyplin naukowych propozycje przeciwdziałania negatywnym skutkom nadmiaru informacji $\mathrm{i}$ związanego $\mathrm{z}$ nim przeciążenia poznawczego wciąż pozostają w sferze teoretycznych postulatów.

\footnotetext{
1 Termin ,informacja naukowa” przez bibliotekoznawców (i bibliologów) nie był i nie jest rozumiany jako synonim terminu „bibliotekoznawstwo” (patrz choćby nazwa kierunku studiów: bibliotekoznawstwo i informacja naukowa). Zaś pojęcia „nauka o informacji”, „bibliotekoznawstwo” i „bibliologia” odnoszą się do różnych przedmiotów badawczych i choć dyscypliny naukowe, które oznaczają mają wspólne obszary badawcze, terminy powyższe nie są tożsame.
} 